\title{
Molecular Characterization and Phylogenetic Analyses of Oestrus ovis Larvae Causing Human Naso-pharyngeal Myiasis Based on CO1 Barcode Sequences
}

\author{
Insan Naso-pharyngeal Myiasis'ine Neden Olan Oestrus ovis Larvalarnnin \\ CO1 Barkod Sekanslarna Göre Moleküler Karakterizasyonu ve \\ Filogenetik Analizi
}

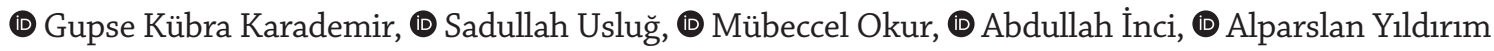
Erciyes University Faculty of Veterinary Medicine, Parasitology Department, Kayseri, Turkey

Cite this article as: Karademir GK, Usluğ S, Okur M, İnci A, Yıldırım A. Molecular Characterization and Phylogenetic Analyses of Oestrus ovis Larvae Causing Human Naso-pharyngeal Myiasis Based on CO1 Barcode Sequences. Turkiye Parazitol Derg 2020;44(1):43-7.

\begin{abstract}
Objective: The identification and molecular characterization of the bot fly larvae from an infected human with naso-pharyngeal myiasis in Turkey were aimed in this study.

Methods: A total of 8 bot fly larvae from a 49-year-old woman with naso-pharyngeal infection in Adana province constituted the materials of this study. Morphological identification was performed on the larvae according to described keys. The barcode region of the $\mathrm{CO} 1$ gene from the genomic DNA extracts of the larvae was amplified and sequence analyses were utilized. Haplotype and genetic distance analyses were performed in $\mathrm{CO} 1$ sequences and a phylogenetic tree was built revealing phylogenetic relationships. Results: All bot fly larvae were identified as second stage larvae of Oestrus ovis in terms of morphologic characteristics. There was no polymorphism among the CO1 sequences of all isolates leading to detection of a single novel haplotype. The newly characterized haplotype in this study clustered with the O. ovis haplotypes from Bosnia and Herzegovina, Croatia, Brazil, and Iran in a monophyletic clade with an overall identity of $99.5 \%$. Interspecific genetic differences among the subfamilies of Oestridae were in the range of $19.8 \%$ to $30.8 \%$.

Conclusion: This study has provided the first molecular characterization data on O. ovis larvae from an accidental human host in Turkey based on $\mathrm{CO} 1$ barcode sequences.
\end{abstract}

Keywords: Oestrus ovis, human naso-pharyngeal myiasis, DNA barcoding, molecular characterization, Turkey

Öz

Amaç: Bu çalışmada, naso-pharyngeal myiasis ile enfekte bir insandan elde edilmiş bot sineği larvalarının identifikasyonu ve moleküler karakterizasyonu amaçlanmıştır.

Yöntemler: Adana bölgesinde naso-pharyngeal myiasis enfeksiyonu olan 49 yaşındaki bir kadından elde edilen sekiz adet bot sineği larvası çalışmanın materyalini oluşturmuştur. Larvaların teşhis anahtarlarına göre morfolojik teşhisleri yapılmıştır. Larva örneklerinin genomik DNA ekstraktlarında barkod CO1 geni amplifiye edilmiştir. CO1 sekanslarında haplotip ve genetik farklılık analizleri yapılmış ve ilişkileri göstermek için filogenetik ağaç oluşturulmuştur.

Bulgular: Morfolojik özelliklerine göre tüm bot sineği larvaları O. ovis' in ikinci dönem larvası olarak teşhis edilmiştir. İzolatların CO1 sekansları arasında polimorfizm belirlenmemiş olup bu sonuç O. ovis için yeni bir haplotipin varlı̆̆ını ortaya çıkarmıştır. Çalışmada yeni karakterize edilen haplotip Bosna-Hersek, Hırvatistan, Brezilya ve İran'dan rapor edilmiş O. ovis haplotipleriyle ortalama \%99,5 identiklik göstererek kümelenme göstermiştir. Oestridae alt aileleri arasındaki interspesifik genetik farklllıklar \%19,8-\%30,8 olarak belirlenmiştir.

Sonuç: Bu çalışma Türkiye'de rastlantısal bir insan konakta belirlenen O. ovis larvaları üzerine CO1 barkod sekansları temelinde ilk moleküler karakterizasyon verilerini sağlamıştır.

Anahtar Kelimeler: Oestrus ovis, insan naso-pharyngeal myiasis, DNA barkodlama, moleküler karakterizasyon, Türkiye

Received/Geliş Tarihi: 02.03.2020 Accepted/Kabul Tarihi: 05.03.2020

Address for Correspondence/Yazar Adresi: Gupse Kübra Karademir MD, Erciyes University Faculty of Veterinary Medicine, Parasitology

Department, Kayseri, Turkey

Phone/Tel: +90 3522076666 E-mail/E-Posta: gupsekarademir@gmail.com ORCID ID: orcid.org/0000-0002-3594-1770 


\section{INTRODUCTION}

The infestations caused by larvae of Diptera in animals and humans are known as myiasis. The larvae belong to the species of Calliphoridae, Sarcophagidae and Oestridae families are the most common and important causative myiases agents (1). Oestridae is a diverse family of Diptera comprising about 180 described species worldwide and their larvae have a variety of feeding habits, mostly saprophages, endoparasites, parasitoids, and predators (2). They cause often severe economic losses by reducing production, causing damages to hides and increasing treatment costs. Myiasis caused by $O$. ovis has a global distribution, especially in rural and underdeveloped regions of tropical and subtropical areas. Domestic sheep and goats are thought to be the main host and also reservoir to other hosts especially those in wildlife (3). The transmission of $O$. ovis occurs when females deposit larvae onto the nostrils of sheep and goats. Their movement and development in the nasal-sinus cavities can cause pathologic and clinical symptoms including rhinitis, frequent sneezing, nasal discharge, breathing difficulties, and emaciation. The annoyance of the adult flies can also lead to significantly reduced animal production by effecting meat, wool and milk production (2). The gravid females are not strictly host-specific and even only a few reports (4), ophthalmic and naso-pharyngeal myiasis also occurred in humans especially the ones close relationship to livestock in several countries.

Oestrosis caused by $O$. ovis also common in sheep and goats in Turkey and several studies have reported a prevalence rate of $36 \%$ to $59 \%$ in different regions (5-7). Sporadic cases of human ophthalmic and naso-pharyngeal myiasis have been also documented from some regions in Turkey (8-12). However, there has been no study regarding molecular and phylogenetic characterization of $O$. ovis lineages found in Turkey except a single GenBank record of partial mt-CO1 sequence of an isolate from Diyarbakır province (GenBank accession: KT761199).

Molecular phylogenetic studies on $O$. ovis populations are very limited compared to the studies based on etiology, taxonomy, biology, immunology, treatment and control approaches. Mitochondrial DNA (mtDNA) is a useful tool for evaluating genomic differences and homologies among taxonomically related species of both vertebrates and invertebrates. Due to its high number of copies, easier isolation, and high phylogenetic signal and mutational rates, mtDNA has been widely used for taxonomic, population and evolutionary investigations across metazoan taxa (13-15). The 658 bp region of CO1 is widely accepted as a universal and standard marker for all animal taxa (14). During the last decade, DNA barcoding using CO1 sequences has provided an efficient tool for molecular identification and phylogenetic characterization of several kinds of insect species including Oestridae family (16-19).

In this study, we aimed to characterize the O. ovis larvae from an infested human with naso-pharyngeal myiasis by using CO1 barcode sequences. Phylogenetic relationships among the identified larvae and the corresponding species in the Oestridae were also revealed in the study.

\section{METHODS}

\section{Bot Fly Larvae from a Human with Naso-pharyngeal Myiasis}

A total of 8 bot fly larvae obtained from a 49-year-old woman with naso-pharyngeal myiasis living in Adana province were sent to parasitology laboratory in the sterile tubes with $70 \%$ ethanol by a public veterinarian working in the same province. No need to take ethical approval for the study according to directions of the Erciyes University Local Ethics Committee for Animal Experiments with the date 29.01.2016 and no 04 due to the material comprised of insect species. The identification of fly larvae was utilized under a stereo microscope (SZX16, Olympus, Japan) with the identification keys described by Zumpt (1) and the images were recorded.

\section{Genomic DNA Extraction and PCR Amplification of C01 Gene}

Genomic DNA (gDNA) was extracted from the tissue sections of each individual larvae specimens using GeneJET gDNA Purification Kit (Thermo Fisher Scientific, USA). The tissue pieces from the larvae were homogenized with the TissueLyser LT (Qiagen, UK) prior to gDNA extraction. The gDNA concentration of larvae was measured by Qubit Fluorometric Quantitation (Thermo Fisher Scientific, USA) to determine the optimum amount of DNA in the PCR mastermix. gDNA isolates were stored at $-20^{\circ} \mathrm{C}$ until PCR analyses.

The universal barcode region of $\mathrm{CO} 1$ gene (709 bp) of the individual larvae was amplified using the common primers of Folmer et al. (20). Amplifications were utilized in C1000 Touch ${ }^{\mathrm{TM}}$ Thermal Cycler (Bio-Rad, USA) using described conditions (20) by adjusting the annealing temperature to $50{ }^{\circ} \mathrm{C}$. The amplicons were visualized in the Fusion FX Gel Documentation System (Vilber Lourmat, France) by loading $5 \mu \mathrm{L}$ of PCR products on $1.5 \% \mathrm{w} / \mathrm{v}$ agarose gel.

\section{C01 Sequence Analysis and Phylogenetic Relationships of Bot Fly}

PCR products were gel purified using a commercial kit (Thermo Fisher Scientific, USA) and purified amplicons were sequenced in both directions with the amplification primers in the Sanger Sequencing Platform (Macrogen, Netherlands). The primer sequences in all reads were trimmed prior to analyses. The final forward and reverse sequences were assembled in Geneious Prime 2019.2.1 (https://www.geneious.com) and a single consensus sequence was obtained with the De Novo Assemble tool in the related software.

The final sequences were searched in the NCBI database by using the BLASTn algorithm. A CO1 data set was constituted with totally 22 sequences belong to genetically related sequences from different countries in the GenBank for phylogenetic analyses. Multiple alignments of the sequences in CO1 dataset were utilized using MUSCLE plugin in Geneious Prime (21). DNA polymorphism and haplotype analyses were performed with DnaSp v.5.1 (22). Intraspecific and interspecific differences were calculated in MEGA 7 (23) using the Kimura two-parameter model (24).

For inferring phylogenetic relationships in the CO1 dataset Maximum Likelihood (ML) estimation was utilized. GTR+G+I was determined as the suitable DNA substitution model for ML analyses using the software jModeltest v.0.1.1 (25). The plugin of PhyML in Geneious Prime was used for the construction of ML tree (26). The reliability of branching of the ML tree was analyzed using a bootstrap resampling of 1000 replications. 


\section{RESULTS}

\section{Human Case of Naso-pharyngeal Myiasis}

A 49-year-old woman living in Adana province was diagnosed with naso-pharyngeal myiasis in the hospital. In our conversation, she complained of about two months of nasal pruritus and sensation of congestion with sanguinolent discharge from her nostrils. She also reported having frequent sneezing, coughing, tear in gland nausea in the related period. After getting non-specific medical approaches such as using cortisone or decongestants two bot fly larvae were dropped. Following the detection of these parasites, she got antiparasitic treatment and further six larvae were dropped from the nostrils.

\section{Morphologic Identification of the Bot Fly Larvae}

All the eight larvae were sent to our parasitology laboratory and identified as second stage larvae of $O$. ovis according to the morphological features under stereo microscope (Figure 1). The size of larvae specimens was $4-5 \mathrm{~mm}$ and they demonstrated anterior hooks, dark posterior spiracles with a flat side medially, and respiratory holes arranged radially.

\section{Sequence Characterization and Phylogenetic Relationships}

The barcode region of CO1 mtDNA was successfully amplified for all the eight isolates in PCR analyses (Figure 2). The consensus sequences covering the $658 \mathrm{bp}$ barcode $\mathrm{CO} 1$ region from all reads were successfully obtained with high-quality chromatogram scores. The sequences were validated by translation analyses with the absence of insertions, deletions, or stop codons indicating functional mitochondrial products. The BLASTn analysis of the obtained sequences confirmed the morphological identifications as the specimens belonged to O. ovis. No polymorphic sites were

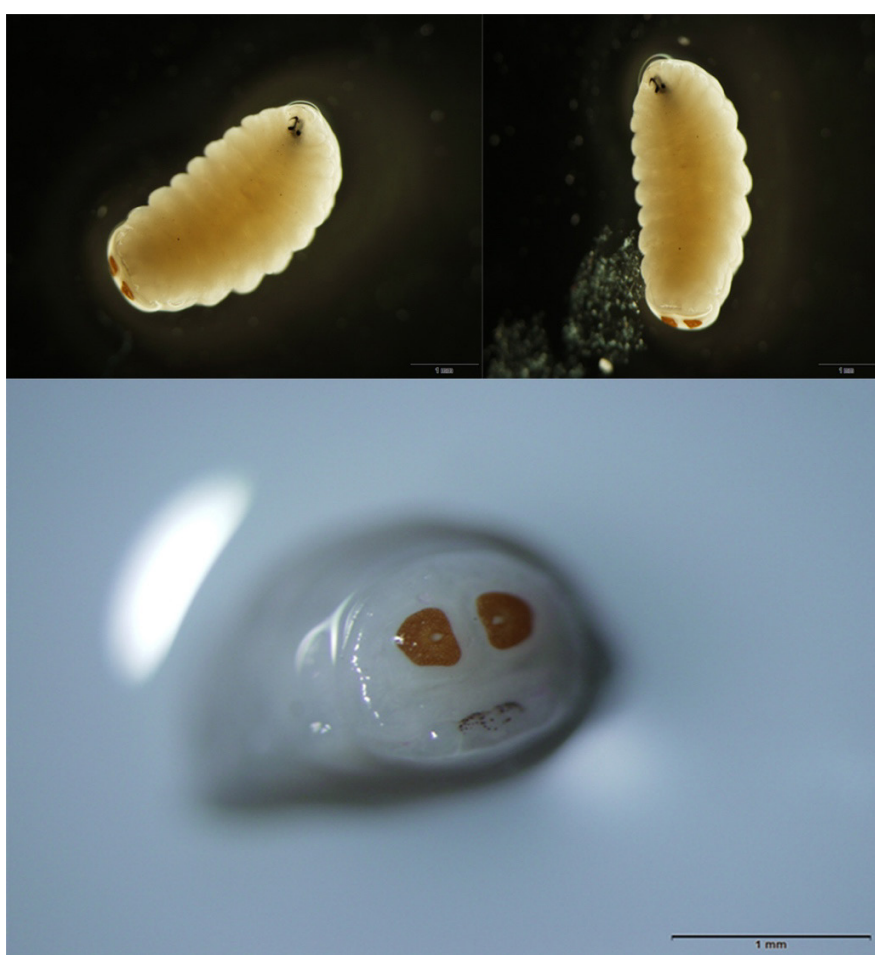

Figure 1. Second stage larvae of $O$. ovis causing human nasopharyngeal myiasis found among the CO1 sequences of all eight isolates resulting in the detection of a single haplotype (ERU-Oov1). The CO1 sequence of ERU-Oov1 was deposited to the GenBank with accession MT124626. The base composition of the barcode sequence of the obtained haplotype was highly AT biased with a mean GC content of $34.2 \%$.

A total of 303 polymorphic sites, of which 244 were parsimony informative, were determined within the entire CO1 data set including the sequences of the species belonging to Gasterophilinae, Cuterebrinae, Oestrinae, Cephenemyiinae and Hypodermatinae subfamilies of Oestridae. Totally four different haplotypes were determined among the $\mathrm{CO} 1$ sequences of the O. ovis and the ERU-Oov1 represented a new haplotype of the corresponding species. Mean haplotype and nucleotide diversities for $O$. ovis were 0.900 and 0.026 , respectively. Intraspecific nucleotide differences for $O$. ovis were determined within range of $0.00 \%$ to $0.61 \%$ and the mean genetic difference was $0.37 \pm 0.15 \%$. Interspecific differences among the subfamilies of Oestridae in the CO1 data set were presented in Table 1 . The species of Hypodermatinae and Cuterebrinae; Cephenemyiinae and Oestrinae were closer to each other as sister taxon. The species of Gasterophilinae were clustered into two distinct clades and found more distant from other subfamilies of Oestridae and the clade including Cobboldia species constituted outer taxa (Figure 3).

The ML tree is presented in Figure 3 with bootstrap support values. All the sequences classified within species-based clades in subfamily taxa with the support of bootstrap values over $69.0 \%$. The novel ERU-Oov1 haplotype clustered in a monophyletic clade with the published haplotypes of $O$. ovis indicated in Figure 3 with a high bootstrap value (100.0\%). The ERU-Oov1 was exhibited highest identity of $99.5 \%$ to the $O$. ovis isolates reported from Bosnia and Herzegovina (MG755264), Croatia (MN845130) and Brazil (KR820703) and also showed an identity rate of $99.4 \%$ to the isolate reported from Iran (KX268655).

\section{DISCUSSION}

A naso-pharyngeal myiasis case in a woman living in Adana province was determined and the recovered bot fly larvae identified as the second stage larvae of $O$. ovis based on the morphological characters. The size and the shape of larvae and the shape of posterior spiracles were consistent with those reported by Zumpt (1). The clinical signs of the infection in the woman patient also consistent with the several naso-pharyngeal myiasis

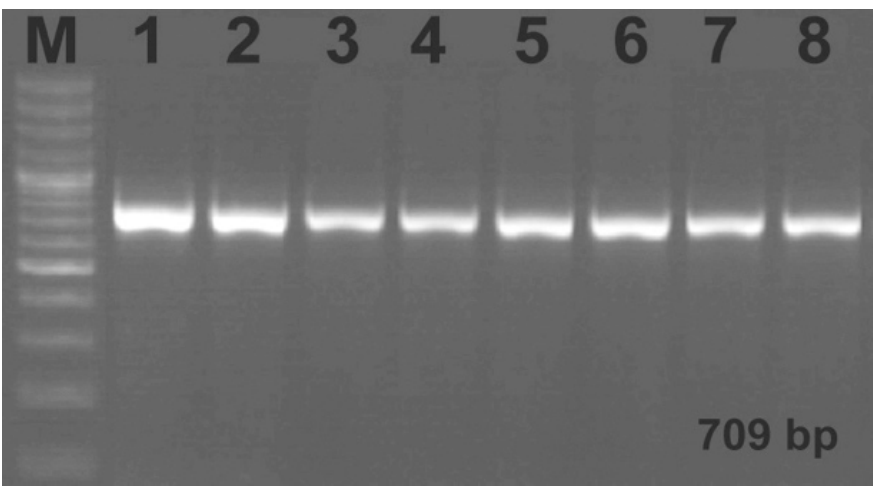

Figure 2. $\mathrm{PCR}$ amplicons of the barcode $\mathrm{CO} 1$ region of $O$. ovis isolates. M: Marker (100 bp), 1-8: gDNA from O. ovis larvae specimens 


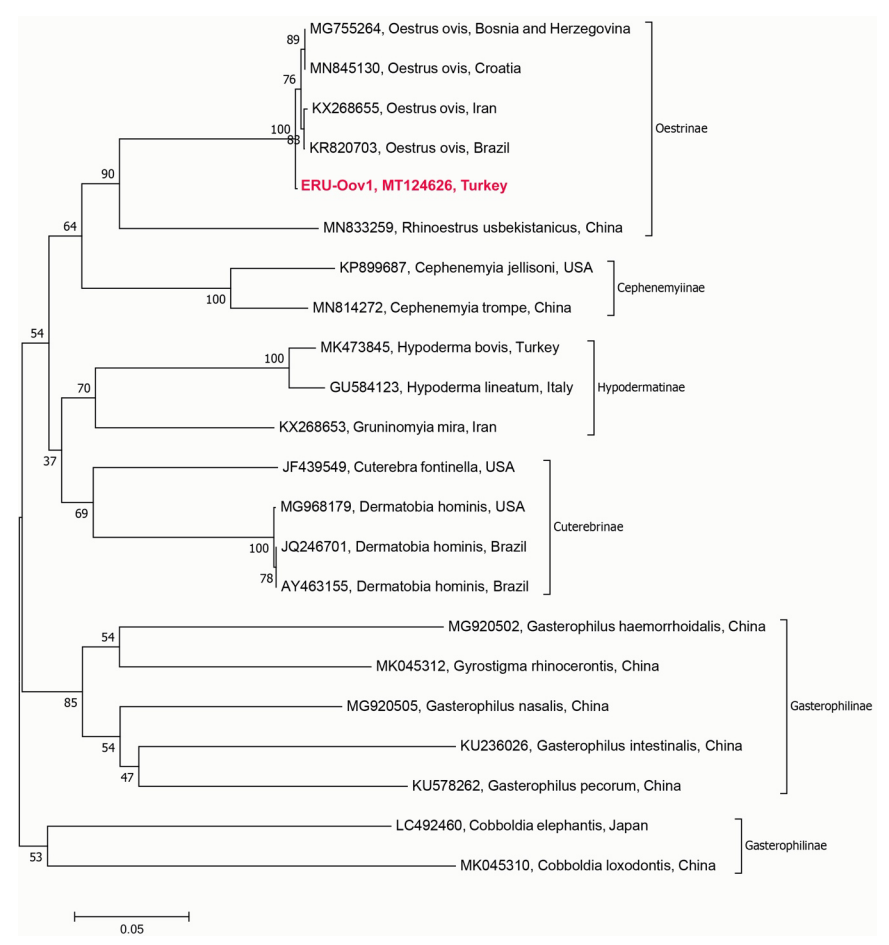

Figure 3. Phylogenetic analysis of $O$. ovis and other species of Oestridae subfamilies. The characterized haplotype was shown in bold red character. Bootstrap values (1000 replicates) was shown at the nodes. The scale bar represents a $0.05 \%$ divergence

Table 1. Interspecific genetic distances (below the diagonal) \pm standard deviations (above the diagonal) for Oestridae subfamilies

\begin{tabular}{|l|l|l|l|l|l|l|}
\hline & & $\mathbf{1}$ & $\mathbf{2}$ & $\mathbf{3}$ & $\mathbf{4}$ & $\mathbf{5}$ \\
\hline 1 & Oestrinae & - & 0.021 & 0.022 & 0.022 & 0.022 \\
\hline 2 & Cephenemyiinae & 0.203 & - & 0.022 & 0.020 & 0.024 \\
\hline 3 & Cuterebrinae & 0.221 & 0.226 & - & 0.019 & 0.021 \\
\hline 4 & Hypodermatinae & 0.234 & 0.212 & 0.198 & - & 0.022 \\
\hline 5 & Gasterophilinae & 0.284 & 0.308 & 0.277 & 0.296 & - \\
\hline
\end{tabular}

cases reported from several countries including Turkey (27-32). Accidental myiasis caused by $O$. ovis larvae has been also reported from conjunctival sac (ophthalmomyiasis) (33), the throat (34), the nose (35), and the ears of humans (36).

Molecular data are still rather limited for bot flies, and the data currently available for Oestridae include mainly partial sequences of mitochondrial genes especially CO1. However, most of the sequences available in GenBank are from different fragments of $\mathrm{CO} 1$ rather than $658 \mathrm{bp}$ barcode region commonly used as a diagnostic marker (13-15). Therefore, it is not possible to compare all $\mathrm{CO} 1$ sequences of bot flies including O. ovisin our study. However, it was obvious that the barcode region successfully discriminates the species in all subfamilies of Oestridae with relatively high rate of barcoding gaps. Our result is also consistent with the findings of Otranto et al. (37), who reported significant interspecific divergences among the 18 species of Oestridae that cause myiasis by using a different fragment of $\mathrm{CO} 1$ as a phylogenetic marker. With only available four O. ovis barcode sequences in GenBank, our newly characterized haplotype clustered together with those reported from Bosnia and Herzegovina (MG755264), Croatia (MN845130), Brazil (KR820703) and Iran (KX268655) in a monophyletic clade and intra-specific genetic distance among the haplotypes were equal or less than $0.6 \%$. This result may indicate a possible low polymorphism in this species with scarce gene flow among the populations from different geographical regions. Low intra-specific distances based on different fragments of $\mathrm{CO} 1$ from other bot fly species such as Przhevalskiana silenus $(18,37)$, Hypoderma bovis, H. lineatum, H. diana, H. tarandi, Gasterophilus intestinalis, G. haemorrhoidalis, G. nasalis and Cuterebra baeri (37) in different countries were also emphasized and all these results might provide an evidence on the absence or lower cryptic diversity in the species of Oestridae. However, for a better understanding of the evolution of $O$. ovis, more comprehensive set of samples from different regions of Turkey and also the world is needed to be analyzed by using both mitochondrial and nuclear markers preferably mitogenomes.

\section{CONCLUSION}

This study provides the first molecular characterization data on O. ovis larvae causing naso-pharyngeal myiasis in a human in Turkey based on barcode $\mathrm{CO} 1$ sequences. Although limited sequences were included in the data set, our findings revealed an evidence on the close association within $O$. ovis from different countries. The barcode $\mathrm{CO} 1$ sequence analyses were successfully differentiate the species of the subfamilies in Oestriade and this result indicates the usefulness of the $\mathrm{CO} 1$ as a suitable diagnostic molecular marker for identification and characterization of bot fly species.

Acknowledgements: The authors thank Nuri Güngör, DVM for giving kind information on the naso-pharyngeal myiasis human case and also providing and sending the larvae specimens to our laboratory.

\section{${ }^{*}$ Ethics}

Ethics Committee Approval: As this study conducted on insect species, there was no need to take ethical approval.

Informed Consent: Patient approval has not been obtained in case of using insect species in the study.

Peer-review: Externally and internally peer-reviewed.

\section{* Authorship Contributions}

Concept: G.K.K., A.Y., Design: A.Y., G.K.K., M.O., S.U., A.I., Data Collection or Processing: G.K.K., A.Y., M.O., S.U., Analysis or Interpretation: A.Y., G.K.K., M.O., S.U., A.I., Literature Search: S.U., G.K.K., M.O., Writing: A.Y., G.K.K., M.O., S.U., I.A.

Conflict of Interest: No conflict of interest was declared by the authors.

Financial Disclosure: The authors declared that this study received no financial support.

\section{REFERENCES}

1. Zumpt F. Myiasis in Man and Animals in the Old-world Ed. London: Butterworth, 1965.

2. Scholl PJ, Colwell DD, Cepeda-Palacios R. Myiasis (Muscoidea, Oestroidea). In: Mullen GR, Durden LA, editors. Medical and Veterinary Entomology. London: Academic Press; 2019. p.383-419. 
3. Colwell DD. Bot flies and warble flies (Order Diptera: Family Oestridae). In: Samuel WM, Pybus MJ, Kocan AA, editors. Parasitic Diseases of Wild Mammals, London: Manson Publishing/The Veterinary Press; 2001. p.46-71.

4. Panadero-Fontán R, Otranto D. Arthropods affecting the human eye. Vet Parasitol. 2015;208:84-93.

5. Gokcen A, Sevgili M. Prevalence and larval burden of Oestrus ovis in Awassi sheep from Sanliurfa region of Turkey. Indian Vet J .2004;81:1168-1169.

6. Uslu U, Dik B. Prevalence and intensity of Oestrus ovis in Akkaraman sheep in the Konya region of Turkey. Med Vet Entomol. 2006;20:347-349.

7. Arslan MO, Kara M, Gicik Y. Epidemiology of Oestrus ovis infestations in sheep in Kars province of north-eastern Turkey. Trop Anim Health Prod. 2009;41:299-305.

8. Yar K, Özcan AA, Koltaș İS. External ophthalmomyiasis: case reports. Turkiye Parazitol Derg. 2011;35:224-226.

9. Akdemir MO, Ozen S. External ophthalmomyiasis caused by Oestrus ovis misdiagnosed as bacterial conjunctivitis. Trop Doct. 2013;43:120-123.

10. Calışkan S, Ugurbaş SC, Sağdık M. Ophthalmomyiasis externa: three cases caused by Oestrus ovis larvae in Turkey. Trop Doct. 2014;44:230-232.

11. Istek Ş. Ophthalmomyiasis externa from Hakkari, the south east border of Turkey. BMJ Case Rep. 2014;bcr2013201226.

12. Özyol P, Özyol E, Sankur F. External ophthalmomyiasis: a case series and review of ophthalmomyiasis in Turkey. Int Ophthalmol. 2016;36:887891.

13. Hebert PD, Penton EH, Burns JM, Janzen DH, Hallwachs W. Ten species in one: DNA barcoding reveals cryptic species in the neotropical skipper butterfly Astraptes fulgerator. Proc. Natl Acad Sci USA. 2004;41:1481214817.

14. Hebert PD, Stoeckle MY, Zemlak TS, Francis CM, Identification of birds through DNA Barcodes. PLoS Biol. 2004;2:e312.

15. Hebert PD, Gregory TR. The promise of DNA barcoding for taxonomy. Syst Biol. 2005;54:852-859.

16. Moreno V, Romero-Fernández I, Marchal JA, Beltrán M, Granados JE, Habela MA, et al. Molecular characterization of bot flies, Oestrus spp. (Diptera, Oestridae), from domestic and wild Bovidae hosts.Vet Parasitol. 2015;212:473-477.

17. Cavallero S, Pombi M, Perrone V, Milardi GL, D’Amelio S, Giuliani C, et al. Gasterophilus intestinalis (Diptera: Oestridae) in the diaphragmatic muscle: An unusual finding. Vet Parasitol. 2017;237:117-121.

18. Rakhshandehroo E, Razavi SM, Farzaneh R, Esmailnejad A, Asadpour M, Shams S. Phylogenetic analysis of goat warble fly (Przhevalskiana silenus) based on mitochondrial COI gene. J Parasit Dis. 2019;43:304-307.

19. Li XY, Pape T, Zhang D. Gasterophilus flavipes (Oestridae: Gasterophilinae): A horse stomach bot fly brought back from oblivion with morphological and molecular evidence. PLoS One. 2019;14:e0220820.

20. Folmer O, Black M, Hoeh W, Lutz R, Vrijenhoek R. DNA primers for amplification of mitochondrial cytochrome $\mathrm{c}$ oxidase subunit I from diverse metazoan invertebrates. Mar Biotechnol (NY). 1994;3:294-299.
21. Edgar RC. MUSCLE: multiple sequence alignment with high accuracy and high throughput. Nucleic Acids Res. 2004;32:1792-1797.

22. Librado P, Rozas J. DnaSP v5: a software for comprehensive analysis of DNA polymorphism data. Bioinformatics. 2009;25:1451-1452.

23. Kumar S, Stecher G, Tamura K. MEGA7: Molecular evolutionary genetics analysis version 7.0 for bigger datasets. Mol Biol Evol. 2016;33:18701874.

24. Kimura M. A simple method for estimating evolutionary rates of base substitutions through comparative studies of nucleotide sequences. J Mol Evol. 1980;16:111-120.

25. Posada D. jModelTest: phylogenetic model averaging. Mol Biol Evol. 2008;25:1253-1256.

26. Guindon S, Gascuel O. A simple, fast, and accurate algorithm to estimate large phylogenies by maximum likelihood. Syst Biol. 2003;52:696-704.

27. Verstrynge K, Foets B. External ophthalmomyiasis: a case report. Bull Soc Belge Ophtalmol. 2004;67-71.

28. Yaghoobi R, Tirgari S, Sina N. Human auricular myiasis caused by Lucilia sericata: clinical and parasitological considerations. Acta Med Iran. 2005;43:155-157.

29. Akdemir MO, Ozen S. External ophthalmomyiasis caused by Oestrus ovis misdiagnosed as bacterial conjunctivitis. Trop Doct. 2013;43:120-123.

30. Najjari M, Shafiei R, Fakoorziba MR. Nosocomial myiasis with Lucilia sericata (Diptera: Calliphoridae) in an ICU patient in Mashhad, Northeastern of Iran. Arch Iran Med. 2014;17:523-525.

31. Alizadeh M, Mowlavi G, Kargar F, Nateghpour M, Akbarzadeh K, Hajenorouzali-Tehrani M. A review of myiasis in Iran and a new nosocomial case from Tehran Iran. J Arthropod Borne Dis. 2014;8:124131

32. Hazratian T, Tagizadeh A, Chaichi M, Abbasi M. Pharyngeal Myiasis Caused by Sheep Botfly, Oestrus ovis (Diptera: Oestridae) Larva, Tabriz, East Azarbaijan Province, Iran: a Case Report. J Arthropod Borne Dis. 2017;11:166-170.

33. Fries FN, Pattmöller M, Seitz B, Berger F, Kampen H, Szentmáry N, et al. Ophthalmomyiasis externa due to Oestrus ovis in a traveller returning from Greece. Travel Med Infect Dis. 2018;23:101-102.

34. Masoodi M, Hosseini K. The respiratory and allergic manifestations of human myiasis caused by larvae of the sheep bot fly (Oestrus ovis): A report of 33 pharyngeal cases from southern Iran. Ann Trop Med Parasitol. 2003;97:75-81.

35. Hoyer P, Williams RR, Lopez M, Cabada MM. Human nasal myiasis caused by Oestrus ovis in the highlands of Cusco, Peru: report of a case and review of the literature. Case Rep Infect Dis. 2016;2456735.

36. White ZL, Chu MW, Hood RJ. Nasal myiasis: A case report. Ear Nose Throat J. 2015;94:E24-25.

37. Otranto D, Traversa D, Guida B, Tarsitano E, Fiorente P, Stevens JR. Molecular characterization of the mitochondrial cytochrome oxidase I (COI) gene of Oestridae larvae causing obligate myiasis. Med Vet Entomol. 2003;17:307-315. 